THUFULI: Jurnal Pendidikan Islam Anak Usia Dini

Volume 3 Nomor 1 Tahun2021

e-ISSN: $2685161 \mathrm{X}$

\title{
IMPLEMENTASI PENGENALAN GENDER TERHADAP ANAK USIA DINI MELALUI KEGIATAN BERMAIN BOMBIX DI KB NANDA CERIA BOCEK KARANGPLOSO MALANG
}

\author{
Salimatul Ummah \\ Paud Nanda Ceria Karangploso Malang \\ e-mail: ummahsalimatul@gmail.com
}

\begin{tabular}{lcc}
\hline Diterima: 9 April $2021 \quad$ I Direvisi: 20 Mei $2021 \quad$ I Disetujui: 22 Mei 2021 \\
C2021 Pendidikan Guru Raudhatul Atfhal Fakultas Agama Islam Universitas Islam Malang
\end{tabular}

\begin{abstract}
This study aimed to describe the implemetation of gender recognition in early childhood through playing Bombix at the Nanda Ceria play group, Bocek, Karangploso, Malang. This research uses a descriptive qualitative approach. Research subjects are early childhood aged 3-4 years, class teacher, and head of institutions. The results of this study indicate that the introduction of gender to early childhood is caaried out playing Bombix activities which are arranged by children according to predesigned themes/sub themes. The results of the implementation of the implementation of gender rocognition in early childhood trough playing Bombix activities are seen when children are assembling Bombix according to their favorite toys that children already know. For example, boys prefer to assemble Bombix into gun masts, robots, fishing rods, while girls prefer to assemble bombix into flower toys, hair clips, and makeup tools. So it can be concluded that playing Bombix is able to provide understanding to children about gender according to their respective gender.
\end{abstract}

Kata Kunci: Gender, Early Childhood, Bombix

\section{A. Pendahuluan}

Dalam rangka pembangunan nasional, pemerintah Indonesia telah melakukan upaya-upaya konkrit dalam mengatasi ketidakadilan HAM \& gender malalui pendidikan dan beberapa kebijakan pengarusutamaan gender (PUG) yang bisa dikenal dengan sebutan Inpres No. 9 Tahun 2000. Sejumlah Undang-undang dan peraturan pemerintah yang ditetapkan sebagai instrumennya, tetapi lebih dari itu diperlukan dukungan riil dari masyarakat agar tujuan PUG dalam mewujudkan masyarakat yang berkesetaraan dan berkeadilan gender untuk mencapai kesejahteraan sosial dapat tercapai (Mufidah, 2010). Namun pada kenyataannya

This work is licensed under Creative Commons Attribution Non Commercial 4.0 International License Available online on: http://riset.unisma.ac.id/index.php/fai/index 
dewasa ini masih banyak sekali terlihat adanya isu-isu tentang diskriminasi gender maupun pelanggaran hak-hak asasi manusia, baik yang dilakukan oleh orang lain atau bahkan oleh orang terdekat seperti keluarga. Mulai dari dari cemoohan atau kata-kata rasis, rundung (bullying), hingga perbuatan yang mencelakai bahkan sampai dengan terjadinya pembunuhan.

Kata gender berasal dari bahasa Inggris yang berarti jenis kelamin, yang menunjukkan adanya penyifatan dan pengklasifikasian dua jenis kelamin secara biologis, yaitu laki-laki dan perempuan. Istilah gender mengacu pada perbedaan sosial antara perempuan dan laki-laki sepanjang siklus hidup yang dipelajari, dan telah berakar dalam setiap budaya, dapat berubah-rubah dari waktu ke waktu dan memiliki banyak perbedaan, baik dalam budaya itu sendiri maupun antar budaya. Jadi secara garis besar pengertian gender merupakan suatu konsep yang mengidentifikasi perbedaan laki-laki dan perempuan, jika dilihat dari segi pengaruh sosial dan budaya.

Anak adalah manusia kecil yang memiliki potensi yang harus dikembangkan serta memiliki karakteristik tertentu yang khas dan tidak sama dengan orang dewasa. Mereka selalu aktif, dinamis, antusias dan ingin tau terhadap apa yang dilihat, didengar, dirasakan. Mereka seolah-olah tak pernah berhenti bereksplorasi serta belajar.Anak bersifat egosentris, memiliki rasa ingin tahu secara alamiah, merupakan makhluk sosial, kaya dengan fantasi dan merupakan masa yang paling potensial untuk belajar. Aspek perkembangan gender diawali dengan determinan genetik jenis kelamin pada saat konsepsi, di mana setiap orang mengalami perkembangan melalui serangkaian tahap perkembangan untuk belajar dari diri sendiri dan lingkungan sebagai laki-laki dan perempuan. Kemudian menginternalisasi identitas tersebut sebagai bagian dari konsep kehidupannya, dan memperoleh hal-hal yang disetujui oleh stereotip gender (gambaran secara umum laki-laki atau perempuan dengan harapan tertentu) budaya, yang akhirnya mengambil sebuah peran gender yang sesuai dan tidak sesuai stereotip gender dari lingkungan di mana anak tinggal.

Berikut merupakan tahapan aspek perkembangan identitas gender anak: (1) Konsepsi adalah janin laki-laki atau perempuan telah dimiliki merupakan penentuan dari gen kromosom. (2) Usia 2-4 tahun. Anak mulai belajar kategori sosial antara laki-laki dan perempuan dan kemudian melabeli diri dan orang lain, walupun dengan pemahaman yang terbatas dari makna secara mendalam. (3) Masa akhir kanak-kanak. Identitas menjadi jelas dan identitas gender (saya lakilaki tau perempuan) berkembang sebagai bagian dari konsep diri. Kemudian anak belajar sesuatu yang menurut budaya disebut sebagai karakteristik gender, dan pada masa ini stereotip gender mulai muncul. (4) Remaja dan dewasa. Pada masa 
ini identitas gender telah dapat dipahami secara yakin dan stereotip gender telah sesuai, dan mengidentifikasi perbedaan antara jenis kelamin laki-laki dan perempuan, yang kemudian menyesuaikan hal tersebut dengan stereotip yang berlaku.

Mengingat begitu pentingnya pendidikan gender kepada anak, agar menanggulangi diskriminasi atau pelanggaran HAM akibat kekurang tahuan tentang gender dan identitas diri, maka setiap jenjang pendidikan harus memiliki program pembelajaran yang mengarahkan untuk anak dapat mengenali arti pentingnya identitas yang dimilikinya. Pembelajaran tersebut termasuk pada jenjang pendidikan pra sekolah/ PAUD. Salah satu pembelajaran tentang pengenalan gender terhadap anak usia dini bisa dilakukan dengan cara bermain sambil belajar yang dapat menstimulus seluruh aspek perkembangan yang dimiliki anak termasuk pengenalan gender. Terlebih pada usia dini merupakan usia yang sangat penting bagi orang dewasa menanamkan fondasi kuat tentang karakter yang akan menunjang masa depan anaknya.

Saharusnya anak usia 3-4 tahun sudah mengenal dan dapat membedakan masing-masing gender yang dimiliki. Namun yang terjadi pada anak usia dini yang ada di Kelompok Bermain (KB) Nanda Ceria Bocek Karangploso Malang dari 15 anak hanya 4 orang anak saja yang sudah mampu mengenal dan membedakan gender mereka. Itu berarti perekembangan karakter yang mereka miliki belum terstimulus dengan maksimal. Berdasakan hal tersebut pendidik KB Nanda Ceria Bocek Karangploso Malang memunculkan permainan yang dapat menstimulus perkembangan karakter anak terutama pada pengenalan gender pada anak usia dini yaitu bermain bombix. Bombix sendiri merupakan alat main bongkar pasang yang berbentuk kepingan, yang sekarang lebih banyak bentuk dan modelnya dari bahan plastik, yang memiliki warna-warna yang bermacam-macam, bisa dirangkai, disusun untuk menjadi berbagai bentuk sesuai dengan keinginan si pemakaianya (Hayati \& Fitri, 2016: 2).

Selain dapat merangsang perkembangan anak tentang gender, pada penelitian sebelumnya yang di lakukan oleh Nur Hayati \& Ruqoyyah Firti (2016) yang berjudul Meningkatkan Kemampuan Mengenal Konsep Bilangan Melalui Bermain Bombik Modifikasi Pada Anak Kelompok Bermain, juga efektif untuk memberi stimulus pada anak usia dini untuk mengenal konsep bilangan. Itu artinya bermain bombix tidak hanya sekedar permainan yang dapat dimainkan oleh anak, namun juga berfungsi untuk meningkatkan setiap aspek yang dimiliki anak.

Berdasarkan penjabaran diatas, tulisan ini dimaksudkan untuk memberikan gambaran serta mendeskripsikan implementasi pendidikan gender melalui 
kegiatan bermain bombix, serta setiap tahapan dalam permainan yang akan membantu anak memahami pendidikan gender yang ia terima.

\section{B. Metode}

Penelitian ini peneliti menggunakan pendekatan kualitatif. Penggunaan metode ini oleh peneliti digunakan untuk pemahaman mendalam tentang bermain bombix: pengenalan gender terhadap anak usia dini. Selanjutnya, hasil temuan penelitian dideskripsikan dengan bahasa yang tepat dan sistematis sesuai dengan fakta-fakta lapangan yang ada dalam penelitian.

Penelitian ini dilakukan di KB Nanda Ceria Bocek Karangploso Malang yang beralamat di Jl. Kauman, No. 02, Desa Bocek, Kecamatan Karangploso, Kabupaten Malang, Provinsi Jawa Timur. Adapun waktu pelaksanaan penelitian yaitu dimulai pada bulan Desember 2020, dimana seluruh pelaksanaan pembelajaran pada seluruh subyek penelitian ditentukan oleh peneliti secara purposive sampling, yaitu anak dari KB Nanda melalui metode wawancara dan dokumentasi sebagai teknik utama untuk mengumpulkan data dalam penelitian.

\section{Hasil dan Pembahasan}

Berdasarkan hasil wawancara bersama Ibu Is (guru kelas) yang menyatakan bahwa pengenalan gender pada anak usia dini dapat dilakukan dengan pembiasaan dan kegiatan bermain sambil belajar. Untuk pembiasaan sudah setiap hari dilakukan, dengan cara mengelompokkan antara laki-laki dan perempuan, atau ketika toilet training, atau sedang melaksanakan kegiatan sholat. Sedangkan untuk kegiatan belajar dan bermain banyak sekali permainan yang dapat merrangsang pengetahuan anak tentang gender yang mereka miliki, salah satunya dengan bermain bombix.

Menurut Bhuiyan (2007) pendidikan di sekolah merupakan salah satu proses sosialisasi yang penting dimana anak mendapatkan pengalaman di luar rumah. Hal tersebut menguatkan pemahaman anak tentang dirinya dalam relasi dengan orang lain. Sekolah dan guru memainkan peranan yang sangat penting dalam usia pembentukan anak. anak-anak mulai memahami identitas dirinya melebihi pemahamannya di rumah, peran yang ada dalam anggapan masyarakat. begitu pula dengan pemahaman tentang peran gender tertentu didapatkan dengan jelas ketika mulainya pendidikan di sekolah dan mendapatkan penguatan setiap hari melalui perilaku guru. Lingkungan sekolah merupakan kawasan tempat anakanak diajarkan untuk mendapatkan, mengembangkan, dan menggunakan sumbersumber dari keadaan sekitarnya. Pendidikan secara formal berada pada lingkungan sekolah, dimana anak akan mempelajari banyak tentang relevansi 
identitas gender diri melalui teman-teman sebaya. Di sekolah anak juga akan mempelajari peran gender yang berlaku di sekolah. Masing-masing dari anak lakilaki maupun perempuan mengembangkan perilaku, sikap, dan komitmen yang ddidefinisikan secara langsung atau tidak, sebagai atribut laki-laki atau perempuan yang diterima. Terlebih tiap anak, memainkan peran gender mereka sesuai dengan pengalaman sehari-hari. Perasaan akan sifat maskulin dan feminim akan dipengaruhi oleh teman bermain atau kesempatan bermain, mainan, media, maupun orang dewasa yang dijadikan contoh bagi anak-anak tersebut.

Peran guru adalah memberikan pemahaman kepada anak tentang arti dan tanggung jawab dari identitas dan peran gender mereka, dengan memberikan kesempatan belajar bagi mereka untuk mendapatkan pendidikan seksualitas yang benar. Misal, menghindarkan dan cara melindungi area privasi dari orang lain, dengan tidak diperbolehkannya selain dirinya sendiri untuk menyentuhnya, bagaimana cara meminta pertolongan apabila ada oknum yang ingin menyakiti atau bertindak tidak baik terkait area privasi, sehingga anak akan mendapatkan pengetahuan untuk menjaga dan melindungi dirinya ataupun mengetahui tentang konsekuensi akan tanggung jawab yang mereka pegang.

Selain itu berdasarkan observasi dan dokumentasi yang dilakukan kepada anak KB Nanda Ceria Bocek Karangploso Malang, pada saat kegiatan bermain bombix, bagi anak laki-laki dalam mengenali gender mereka, anak lebih diarahkan untuk membuat atau merangkai mainan menjadi bentuk benda yang lebih identik dengan gender laki-laki atau identitas laki-laki, seperti menjadi bentuk pancing, alat pertanian cangkul, dan mobil-mobilan. Sedangkan untuk yang anak perempuan, mereka lebih menyukai apabila guru membuat contoh dengan merangkai bombix menjadi bunga, penjepit rambut, dan peralatan masak atau alat bersih-bersih seperti sapu, dan lain-lain. Menurut pernyataan bu Is: "Dengan bermain bombix banyak sekali potensi yang mampu terangsang, misal dalam tema diriku sendiri anak, mulai mampu memahami identitas dan peran yang harus dilakukan sesuai dengan lingkungan sekitarnya, seperti anak yang bernama Alvaro, yang ayahnya adalah seorang petani, maka mainan yang dibuatnya adalah alat-alat pertanian, dan anak yang bernama Putri, yang orang tuanya adalah makeup online shoper, jadi yang mainan yang dibuatnya adalah peralatan makeup dan handphone untuk selfie".

Dalam implementasi pengenalan gender pada anak usia dini dengan bermain bombix dengan rencana pembelajaran yang telah disusun sebelumnya, menurut bu Is dengan tema diriku sendiri dan sub tema mainan kesukaanku, anak diberikan kegiatan bermain bombix, di mana anak akan diberikan kesempatan untuk menyusun bombix dan membentuk bentuk mainan yang sesuai dengan 
favorit. Dari kegiatan tersebut, telah didapati bahwa anak laki-laki lebih suka bermain dan menyusun bombix untuk menjadi mobil-mobilan, robot, pistol, pancing dan banyak lagi. Sedangkan anak perempuan lebih suka membuat bunga, mikrofon untuk dipakai menyanyi, sayur, alat makeup, penjepit rambut, dan lain sebagainya. Dari apa yang dilakukan oleh anak-anak dengan bermain bombix mereka telah memahami jika anak laki-laki mainan yang cocok untuknya dan disukai yaitu mainan yang biasanya dilihat dari identitas dan peran gender yang ada di masyarakat sekelilingnya, begitu pula dengan anak perempuan yang terlihat memhami bahwa mainan yang disukai merupakan maianan yang mengarah pada feminisme.

Sedangkan hasil penelitian berdasarkan wawancara bersama orang tua, salah satunya Ibu Cindi (orang tua Alvaro) berpendapat bahwa biasanya orang tua mengenalkan jenis kelamin anak dengan membiasakan anak untuk menggunakan pakaian yang sesuai dengan jenis kelamin mereka atau peralatan yang biasa digunakan oleh ayahnya. Orang tua yang menunjukkan identitas dan perang gender kepada anak seuai dengan jenis kelaminnya, seperti ketika akan membelikan pakaian anak, orang tua biasanya memilihkan gaun/rok bagi anak perempuan dan mainan robot, mobil-mobolan bagi anaknya yang laki-laki. Kemudian dalam pengasuhan orang tua biasanya akan mengarahkan anaknya kepada hal-hal atau kegiatan yang lebih sesuai dengan jenis kelamin, misal, anak laki-laki dengan kegiatan keterampilan merakit, membangun dan anak perempuan kepada kegiatan yang cocok dengan sifat feminisme, seperti memasak, menjahit, berhias.

Salah satu nilai yang ditanamkan dalam keluarga kepada anak adalah gender. Keluarga merupakan agen sosialisasi yang pertama mengajarkan seorang anak laku-laki untuk mengenal sifat maskulin dan feminim bagi seorang anak perempuan. Terdapat tiga hal yang mempengaruhi perkembangan gender, yaitu biologis, yaitu pemahaman tentang pengaruh keturunan, sosial, dimana faktor tersebut muncul dengan adany interaksi yang dilakukan oleh anak dengan lingkungan sekitarnya, dan kognitif, yang menjadi pemahaman bahwa gender terbentuk setelah anak berfikir bahwa dirinya adalah laki-laki dan perempuan, ketika anak dalam masa pengenalan jenis kelamin dan peran gender, tugas utama dari orang tua atau keluarga yaitu memperkenalkan hal-hal yang menunjang pembentukan gender anak sesuai dengan jenis kelaminnya masing-masing. Misal, pemilihan nam, mainan, pakaian, gaya, rambut, warna, dan lain-lain.

Dari hal-hal tersebut di atas, peran orang tua dalam mendidik anak untuk mengembangkan pembentukan gender anak menjadi faktor pertama dan utama bagi anak. Orang tua juga menjadi role model bagi anak dalam mencontoh perilaku 
identitas dan peran gender, di mana apabila seorang ibu ketika memilih baju yang dipakainya adalah feminim, maka anak perempuannya juga akan tampil feminim, atau ibunya lebih menyukai cassual dalam berbusana, maka anaknya juga tidak akan jauh memilih model bajunya. Begitu pula dengan ayah suka mengekspresikan sifat maskulinnya dengan merokok, maka bukan tidak mungklin kelak anaknya juga akan mencontohnya. Oleh karena itu, dalam setiap upaya orang tua dalam membentuk gender anak, hendaknya memberikan contoh baik dan sesuai kepada anak dan tidak melenceng jauh dari jenis kelaminnya masing-masing. Sehingga kemudian anak akan kuat dan tidak akan bimbang dalam menentukan identitas dan peran gender yang ia miliki.

Selain lingkungan keluarga lingkungan masyarakat adalah lingkungan tempat berbaurnya semua komponen masyarakat, baik agama, etnis, budaya, ekonomi maupun sosial. Menurut Ibu Oci (orang tua Putri) lingkungan yang ada disekitar anak juga memberikan pengaruh terhadap perilaku anak, seperti dalam berpakaian, ada anak satu memakai baju ini maka otomatis berpengaruh terhadap perilaku anak sendiri dan itu berlaku juga dengan sifat dan perilaku yang ada dimasyarakat dan sudah tugas orang tua untuk terus memberikan bimbingan dan arahan sikap dan perilaku yang sesuai dengan norma dan adat yang berlaku.

Dari situ dapat disimpulkan bahwa Pengaruh yang ada di masyarakat dapat mempengaruhi anak terhadap pengembangan potensi yang dimiliki anak. Kontrol dari masyarakat juga akan membantu dalam meningkatkan peran dalam pendidikan. Tanpa peran masyarakat maka mustahil pendidikan akan berkembang, karena masyarakat yang akan menentukan mutu pendidikan. Maka hubungan pengaruh lingkungan masyarakat terhadap pembentukan gender anak adalah bahwa Allah SWT telah menciptakan manusia dengan gender masingmasing. Dalam hal peran gender atau identitas gender, Allah telah memberikan perbedaan atau ciri khas yang berlainan antara anak laki-laki maupun perempuan, sementara lingkungan akan berperan sebagai pendukung dari pembentukan melalui pendidikan lingkungan tersebut serta mengembangkannya, maka terciptanya lingkungan yang aman dan kondusif merupakan hal yang harus diupayakan, supaya kedepannya anak akan tumbuh dan berkembang dengan maksimal yang kemudian akan tercipta sumber daya manusia yang berakhlak mulia dan bermanfaat bagi lingkungan tersebut.

\section{Simpulan}

Gender merupakan perbedaaan sosial antara laki-laki dan perempuan, yang sesuai dengan konsep kultural yang ada, baik secara perilaku, mental, dan karakteristiknya, dimana gender juga adalah konsep yang harus diperkenalkan 
sejak usia dini, karena pemahaman identitas gender dan peran gender adalah bagian dari perkembangan psikososial anak, yang harus mendapatkan rangsangan atau stimulus yang tepat, agar kemudian anak mampu mengenali identitas gender dan peran gender yang sesuai dengan jenis kelaminnya masing-masing. Pengenalan gender pada anak usia dini dapat dilakukan dengan cara pembiasaan dan melalui kegiatan bermain, salah satunya adalah kegiatan bermain bombix. Dengan kegiatan bermain bombix anak dapat merangkai alat permainan edukasi tersebut menjadi bentuk-bentuk yang sesuai dengan identitas gender yang dimilikinya, misal anak laki-laki membuat bentuk cangkul, pancing, mobil-mobilan, sedangkan untuk anak perempuan membuat alat make up, sisir, bunga, dan lainlain.

Sedangkan orang tua sebagai pendidik utama dalam keluarga, juga berperan mengenalkan gnder kepada anak, misal dengan memberikan kebutuhan yang sesuai dengan gender anak, misal putri disiapkan baju rok, mencontohkan keterampilan memasak, sedangkan untuk anak laki-laki diberikan mainan mobilmobilan atau peralatan yang biasa dipakai ayah, dan diajarkan keterampilan merakit, membangun, dan lain sebagainya. Selain keluarga masyarakat juga memberikan andil pengaruh terhadap pengenalan gender bagi anak, seperti cara berpakaian kebnaykan orang pasti akan mempengaruhi cara berpakaian anak, begitu pula dengan perilaku dan sikap dari lingkungan orang-orang kebanyakan juga akan mempengaruhi pendidikan gender yang dialami oleh anak. dan menjadi tugas orang tua untuk membimbing dan mengarahkan gender anak sesuai dengan norma dan adat yang berlaku.

\section{Daftar Rujukan}

Hadianti, Asti. (2017).Pendidikan Gender Pada Anak Usia Dini. file://C:/Users/Ok/Downloads/599-Article\%20Text-694-1-1020170427\%20(1).pdf

Kurnia, S. (2018). Implementasi Kesetaraan Gender pada Pendidikan Anak Usia Dini Di Sekolah. file:///C:/Users/Ok/Downloads/230711085.pdf

Montesori, Maria. Tanpa Tahun. Metode Montesori. Terjemah Gutex, Gerald Lee.

2013. Yogyakarta: Pustaka Pelajar.

Pujianti. (2014). Peran Orang Tua Dalam Membentuk Identitas Gender Anak. file://C:/Users/Ok/Downloads/288045-peran-orang-tua-dalampembentukan-identi-6d06eba6.pdf

Purnomo, P., (2009) Pemahaman Anak Prasekolah Mengenai Identitas Gender dan Perang Gender. file://C:/Users/Ok/Downloads/019114082_Full[1].pdf 
Roziqoh \& Suparno. (2014). Pendidikan Berperspektif Gender Pada Anak Usia Dini (Gender Perscpective Education To Early Chilhood). file://C:/Users/Ok/Downloads/2359-6531-1-SM.pdf

Sujiono, Yuliani. (2009). Konsep Dasar Pendidikan Anak Usia Dini. Jakarta. Indeks Sulyandari, Ari. (2019). Pengaruh Gadget pada Perkembangan Anak usia Dini. Thufuli: Jurnal Ilmiah pendidikan Anak usia Dini. 1(1). http://riset.unisma.ac.id/index.php/thufuli/article/view/2712/2591 